\title{
Irrigation performance in private urban landscapes: A study case in
}

\section{Zaragoza (Spain)}

Paper published as:

Salvador, R., Bautista-Capetillo, C., Playán, E. Landscape and Urban Planning. Irrigation performance in private urban landscapes: A study case in Zaragoza (Spain). Landscape and Urban Planning. 100 (2011), pp. 302-311.

\begin{abstract}
Irrigation water use in private landscapes represents an increasing share of total water use in semiarid areas. In this work, 102 households located in the Montecanal neighbourhood (Zaragoza, Spain) were analysed. Research took advantage of the dual water supply network (separate indoor and irrigation water networks). The analysis was based on bi-monthly water billing records for the period 2005-2007. The total household landscape area $\left(93 \mathrm{~m}^{2}\right)$ and the area occupied by turf, trees and shrubs were derived from aerial photographs. A method based on reference evapotranspiration was used to estimate net landscape irrigation requirements. The total average water use was $0.80 \mathrm{~m}^{3}$ household ${ }^{-1} \mathrm{day}^{-1}$, with irrigation water use amounting to $46 \%$ of the total water use. Average air temperature largely determined irrigation water use (the correlation coefficient was 0.958). Overirrigation was common in the three years of study, with the average irrigation water application (IWA) being much higher than the Net Irrigation Requirements (1,359 and $555 \mathrm{~mm}$, respectively). Only $34 \%$ of the households showed adequate irrigation, while $6 \%$ of the households underirrigated their landscape areas. In the rest of the households (60\%), overirrigation was observed. Significant time correlations were found for IWA and for an adequacy index, suggesting that landowners applied their inadequate irrigation criteria in a consistent way. Local private landscape irrigation performance was found to be very poor, probably owing to low water cost and over-the-average household income.
\end{abstract}




\subsection{INTRODUCTION}

The city of Zaragoza is located in the central Ebro basin (northeast of Spain), and has a population of 682,000 . The total population in the Ebro basin is 2.75 million. Urban water use in the Ebro basin has been estimated as $524 \mathrm{M} \mathrm{m3} \mathrm{yr}-1$, representing $7 \%$ of the total basin water use (Confederación Hidrográfica del Ebro, 2010). This figure is small in comparison with other developed urban areas. This is the case of many cities in the USA, where Kjelgren, Rupp and Kilgren (2000) reported that landscape irrigation accounted for 9 to $48 \%$ of total municipal water use. The small percentage of urban to total water uses in the Ebro basin can be attributed to its low population density (35 inhabitants $\mathrm{km}-2$ ) and to the intensity of irrigated agriculture.

The relatively small contribution of urban water use to total Ebro basin water use should not lead to an underestimation of the importance of urban water use in the basin. In fact, urban uses require high water quality (due to the need for purification) and treatment as sewage water. As a consequence, urban water is far more expensive than agricultural water. The variable cost of agricultural water fluctuates from 0.03 to $0.10 € \mathrm{~m}-3$, while the variable cost of urban water in Zaragoza ranges from 0.16 to $0.76 € \mathrm{~m}-3$ (Ayuntamiento de Zaragoza, 2004). Several studies have shown the effect of landscape irrigation water cost on the control of excessive irrigation. This is particularly true in areas characterized by low-middle income and high irrigation water cost (Domene \& Saurí, 2003). Hurd, St-Hilaire and White (2005) showed that water cost was closely related to the choice of landscape species in New Mexico (USA). In general, residential water use is characterized by inelastic demand (Renzetti, 2002): demand variation is a smaller ratio than the ratio of water cost variation. Additionally, Boland, Dziegielewski, Baumann and Opitz (1984) concluded that the magnitude of this inelasticity depended on the specific location, probably depending on the average income.

In most private landscapes in Spain, water used for irrigation is potable water. As a consequence, poor landscape irrigation performance results in high economic and environmental costs. In addition, the Spanish water act gives the highest priority to urban 
uses in the case of drought. As a consequence the characterization of landscape water use is a valuable tool to rationalize water consumption in urban environments and in whole river basins. Landscape irrigation can become a key local water use in the presence of water shortages.

At the beginning of the 21st Century, high urban water cost and recurrent droughts motivated several water saving campaigns in Zaragoza and other cities in Spain (ParésFranzi, Saurí-Pujol \& Domene, 2006). These campaigns focused on a number of issues, including the reduction of irrigation water use in public landscapes. However, the irrigation of private landscapes did not receive much scientific or political attention. The main activity regarding private landscapes was the distribution of leaflets explaining xeriscaping practices at the nurseries supplying ornamental plants to local citizens.

In Zaragoza (as in the rest of Spain), the irrigation of private landscapes has increased in recent years due expanding suburbs as incomes have increased. In these suburbs, most housing developments include private landscapes. By the end of the 20th century, only $5 \%$ of the local homes had private landscapes (Ayuntamiento de Zaragoza, 1999). However, over the past decade a clear trend for the horizontal expansion of the city has been observed. Water used in landscape irrigation at the new urban development has been documented to reach $56 \%$ of the total water use (Loh \& Coghlan, 2003).

In Mediterranean countries turf is generally treated as a positional good (Hirsch, 1976), due to its shortage in natural landscapes. For this reason, it is common to find it as a predominant species in the landscapes of Zaragoza (whether private or public), accompanied by other species typical of temperate, humid climates. The main disadvantage of these species is their high water requirements, which can not be met by the typical precipitation of semiarid environments such as Zaragoza.

Water requirements for landscapes are calculated taking into account different factors, the two most important being the local climate and the type of species present in the landscape. 
Other factors include the coexistence of two or more species in the same area (i.e., turf, trees or shrubs) and factors modifying the climate, such wind exposure. Research work determining landscape water requirements (LWR) usually follows one of three methodological approaches: The first option is to put landscape water requirements at the level of $\mathrm{ET}_{0}$ values (Haley, Dukes \& Miller, 2007). This comparison is logical if most of the landscape area is turf. The second option is based on direct estimation of landscape water requirements through the use of instruments such as volumetric soil water sensors (Morari \& Giardini, 2001; White et al., 2004) or weighing lysimeters (Brown et al., 2001). The last group of authors (Domene \& Saurí, 2003; Contreras, González, López \& Calvo, 2006) follows the methodology proposed by Costello, Matheny and Clark (2000), developers of the WUCOLS method for determining landscape water requirements. The WUCOLS method is based on $\mathrm{ET}_{0}$, and uses an ad hoc procedure to estimate the coefficients that replace the crop coefficient by a landscape coefficient.

Overirrigation has been reported as common in private landscapes, particularly during the fall season (Hunt et al., 2001; White et al., 2004; Endter-Wada, Kurtzman, Keenan, Kjelgren \& Neale, 2008), and in small landscapes (Kjelgren et al., 2000). This is due to the delay in changing the irrigation schedule from summer to fall (a season in which landscape irrigation requirements sharply decrease). These results are in contrast with local agricultural irrigation. Overirrigation is not common in the agricultural irrigated areas of Spain, particularly if pressurized systems are used. Adjustments of irrigation depth to crop water requirements or even moderate underirrigation are common findings in specialized research works (Lorite, Mateos \& Fereres, 2004; Salvador, Martínez-Cob, Cavero \& Playán, 2010).

Irrigation performance (based on the analysis of irrigation water use and on its comparison with irrigation requirements) has been assessed by a number of authors in private and public landscapes. These works reported differences resulting from differences in water price, income (either individual or average in the municipality), plant species, landscape size, irrigation systems, presence of irrigation controllers and feedback of information to the users (Hunt et al., 2001; Domene \& Saurí, 2003; Syme, Shao, Po \& Campbell, 2004; Domene \& Saurí, 2006 and Parés-Franzi et al., 2006). Urban water use in private landscapes 
composed of turf, trees and shrubs has been reported in three cities in Spain: Barcelona (Domene \& Saurí, 2003; Domene \& Saurí, 2006; Parés-Franzi et al., 2006), Murcia (Contreras et al., 2006) and Madrid (Moreno, Ibáñez \& Cubillo, 2007). These references reported that in the local conditions of Spain landscape irrigation water use was related to the municipality income level and to the landscape ownership (private vs. public).

The presence of irrigation controllers is an important issue, since their low cost has resulted in widespread use. Standard (time-based) irrigation controllers (those in which the user has to enter the irrigation schedule) have been found to increase the irrigation water volume as compared with manual irrigation control (Loh \& Coghlan, 2003; Syme et al., 2004 and Endter-Wada et al., 2008). This fact seems to be related to saving time, instead of saving irrigation water. Adjusting the irrigation controller to changes in water requirements is a time consuming task, and many users perceive it as too complicated.

On the other hand, advanced irrigation controllers resulted in significant reductions in water use. A number of research studies analysed the use of irrigation controllers equipped with rainfall sensors (St. Hilaire et al., 2008; McCready, Dukes \& Miller, 2009) or with the capacity of obtaining $\mathrm{ET}_{0}$ estimates (Hunt et al., 2001; Quails, Scott \& DeOreo, 2001; Aquacraft-Inc, 2003; Devitt, Carstensen \& Morris, 2008; Davis, Dukes \& Miller, 2009). These studies demonstrated that advanced irrigation controllers permit to reduce water use by 11 to $75 \%$ as compared with manual irrigation. In addition to conserving irrigation water, some of these studies (Hunt et al., 2001; Devitt et al., 2008) reported an increase in the visual quality of landscape.

Water price is one of the most important factors controlling water use (Baumann, Boland \& Hanemann, 1998; Domene \& Saurí, 2003). Consequently, an adequate water pricing policy seems to be one of the most important tools for decreasing private landscape irrigation water use. When landscape irrigation water is obtained from an agricultural irrigation water supply network, water price is generally too low to induce water conservation in landscape uses. 
The present study was performed in urban private landscapes at the Montecanal housing development (Zaragoza, Spain). The objectives of this work are: 1) To describe the types of vegetation and estimate landscape water requirements; 2) To analyse the bi-monthly variation of irrigation water use and potable water use; and 3) To assess landscape irrigation performance through a comparison of irrigation water use and irrigation requirements. 


\subsection{MATERIALS AND METHODS}

\subsubsection{Area description}

The Montecanal neighborhood was chosen to analyze landscape irrigation performance in selected households. A household consists of all private residential property (building + lanscape + paved areas). Montecanal is a suburb of Zaragoza (Northeast Spain; UTM coordinates 41.6 and -0.9 ), whose residents are characterized by relative medium-high income. The climate in the zone is semiarid, with very hot summers and long, cold winters. The annual average of $\mathrm{ET}_{0}$ and precipitation are 1,198 $\mathrm{mm}$ and $337 \mathrm{~mm}$, respectively.

Montecanal makes an interesting case study since potable water and irrigation water are supplied by two different networks. This is not a common feature in the world, and is certainly infrequent in Spain. While potable water follows a standard treatment, irrigation water is directly supplied from the "Canal Imperial", a canal constituting one of the main sources of urban water for Zaragoza, as well as supplying a large agricultural irrigated area. Each household in Montecanal is equipped with two water meters: One for indoor potable water and one for outdoor water, largely used for landscape irrigation. The maximum water meter error is $\pm 5 \%$ for minimum discharge and $\pm 2 \%$ for maximum discharge. The water price is different for each network. In the period 2005-2007, the cost of potable water was of $0.76 € \mathrm{~m}^{-3}$, while the cost of irrigation water was of $0.17 € \mathrm{~m}^{-3}$ (a cost ratio of 4.5 ).

The study area comprised 134 households occupying cadastral plots with areas ranging between 248 and $532 \mathrm{~m} 2$. The most common household area is $266 \mathrm{~m} 2$, corresponding to $89 \%$ of the analyzed cadastral plots. The total study area is therefore about 5 ha. Most Montecanal households have their own landscape area, surrounded by a tall fence. Landscapes vary in size and species (the most common are turf, ornamental trees and shrubs). Only part of the outdoor area of each household is covered with vegetation. In some households, areas initially designed for landscape have been paved. Pressurized irrigation systems have been installed in the landscape areas. Sprinkler irrigation systems are common in areas where turf prevails. Drip irrigation systems prevail in landscapes planted 
with trees or shrubs. It is very common that a single household uses both irrigation systems, installed in different landscape areas. The use of time-based irrigation controllers is widespread in the area.

\subsubsection{Household area determination}

The characterization of household landscapes was performed using color aerial photographs of the city of Zaragoza obtained from the SITAR (Territorial Information Service) of the Government of Aragón (Gobierno de Aragón, 2008). These images, characterized by a pixel size of $0.1 \times 0.1 \mathrm{~m}$, have undergone radiometric and geographic corrections.

The first step in this analysis was to locate each household in the cadastral database. A Geographic Information System (Arcview (C) GIS 3.3) was used to measure the area of outdoor water uses: landscape (vegetated area) and swimming pools. Three polygon layers were created in the GIS: landscape, trees and shrubs, and swimming pools. The household architectural design often implied the existence of more than one vegetated area. The area occupied only by turf was obtained as the difference between the landscape area and the area devoted to trees and shrubs. An algorithm was applied to determine the area under each category in each household. At the end of this process, the landscape area (divided into turf on one hand, and trees and shrubs on the other) and swimming pool (if there was one) was obtained for each household. The rest of the household area was occupied by the building and the surrounding paved areas.

\subsubsection{Water records}

Bi-monthly records were obtained for the two water meters installed at each household. The study period covered from March 2005 to October 2007. These data permitted us to determine bi-monthly water use for each type of water. The following codes were assigned to the recording periods: Jan-Feb, Mar-Apr, May-Jun, Jul-Aug, Sep-Oct and Nov-Dec. Since 
irrigation water delivery is interrupted from November to February, periods Jan-Feb and Nov-Dec only contain potable water records.

\subsubsection{Agrometeorological data}

Agrometeorological data were obtained from the closest automatic meteorological station belonging to the SIAR network (Sistema de Información Agroclimática para el Regadío, Agroclimatic Irrigation Information System). This network publishes daily FAO Penman-Monteith reference evapotranspiration (Allen, Pereira, Raes \& Smith, 1998) $\left(E T_{0}, \mathrm{~mm}^{\mathrm{day}}{ }^{-1}\right)$, precipitation $\left(P, m m\right.$ day $\left.^{-1}\right)$ and average temperature $\left(T_{m}, \underline{\circ}\right)$, among other variables. The SIAR network was installed by the Ministerio de Medio Ambiente, Medio Rural y Marino of the government of Spain (Ministerio de Medio Ambiente, Medio Rural y Marino, 2008), and is operated in partnership with regional Governments. In this work, $\mathrm{ET}_{0}, \mathrm{P}$ and $\mathrm{T}_{\mathrm{m}}$ records were obtained for the temporal frame of the study (Table 3.1). The highest values of $\mathrm{ET}_{0}$ and $T_{m}$ always corresponded to the Jul-Aug period (2005-2007), with average values of $E T_{0}$ of 387 $\mathrm{mm}$ and $\mathrm{T}_{\mathrm{m}}$ of $23.5 \stackrel{\circ}{\circ} \mathrm{C}$. $\mathrm{ET}_{0}$ and $\mathrm{T}_{\mathrm{m}}$ were slightly lower in May-Jun, with $326 \mathrm{~mm}$ and $19.8 \stackrel{\circ}{\circ} \mathrm{C}$, respectively. In Mar-Apr and Sep Oct, $\mathrm{ET}_{0}$ values were similar (with averages of 186 and 188 $\mathrm{mm}$, respectively), but the differences in $T_{m}$ were substantial: $T_{m}$ was higher in Sep-Oct (average of $17.7 \stackrel{\circ}{\circ}$ ) than in Mar Apr (average of $11.8 \stackrel{\circ}{\circ}$ ). The lowest $\mathrm{ET}_{0}$ and $\mathrm{T}_{\mathrm{m}}$ corresponded to the winter periods. Precipitation was irregular (Table 3.1), with peaks in Mar-Apr of 2007 (158 mm), Sep-Oct of 2006 (132 mm) and May-Jun of 2005 (102 mm).

Table 3.1. Agrometeorological data for $2005-2007$ in the study area. 


\begin{tabular}{ccccc}
\hline Year & Period & $\begin{array}{c}\text { Total ET } \\
(\mathbf{m m})\end{array}$ & $\begin{array}{c}\text { Total P } \\
(\mathbf{m m})\end{array}$ & $\begin{array}{c}\text { Average } \mathrm{T}_{\mathrm{m}} \\
(\mathbf{O} \mathbf{C})\end{array}$ \\
\hline \multirow{2}{*}{2005} & Mar-Apr & 195 & 25 & 11.3 \\
& May-Jun & 343 & 102 & 20.8 \\
& Jul-Aug & 388 & 5 & 23.6 \\
& Sep-Oct & 181 & 66 & 17.5 \\
& Nov-Dec & 66 & 35 & 6.5 \\
\hline \multirow{2}{*}{2006} & Jan-Feb & 71 & 42 & 5.1 \\
& Mar-Apr & 191 & 53 & 12.5 \\
& May-Jun & 330 & 47 & 20.0 \\
& Jul-Aug & 395 & 25 & 24.1 \\
& Sep-Oct & 180 & 132 & 18.9 \\
& Nov-Dec & 55 & 29 & 8.1 \\
\hline \multirow{2}{*}{2007} & Jan-Feb & 73 & 28 & 6.3 \\
& Mar-Apr & 172 & 158 & 11.6 \\
& May-Jun & 304 & 86 & 18.7 \\
& Jul-Aug & 377 & 28 & 22.9 \\
& Sep-Oct & 204 & 49 & 16.8 \\
\hline
\end{tabular}

\subsubsection{Irrigation Requirements}

The WUCOLS (Water Use Classifications of Landscape Series) method, proposed by Costello et al. (2000) was used to estimate landscape irrigation requirements. WUCOLS is based on the application of a landscape coefficient $\left(\mathrm{K}_{\mathrm{L}}\right)$, which is multiplied by $E T_{0}$ to obtain the LWR. $K_{L}$ is determined as the product of the species factor $\left(k_{s}\right)$, the density factor $\left(k_{d}\right)$ and the microclimate factor $\left(k_{m c}\right)$ :

$$
K_{L}=k_{s} k_{d} k_{m c}
$$

The species factor depends of the type of plant and the related water requirements of the species planted in the landscape. These values were tabulated by Costello and Jones (1994) 
for more than 2,000 species in six areas of California. Species were classified as presenting very low requirements $\left(k_{s}<0.10\right)$, low requirements $\left(0.10<k_{s}<0.30\right)$, moderate requirements $\left(0.40<k_{s}<0.60\right)$, and high requirements $\left(0.70<k_{s}<0.90\right)$. In this work, a $k_{s}$ value of 0.82 was assigned to turf. This value is consistent with the high requirements of these species and was obtained as a weighted average of the values reported by Brown et al (2001). The $k_{s}$ value assigned to trees and shrubs was 0.55 , corresponding to species presenting moderate water requirements. This estimation took into account the most common species in private landscapes containing trees and shrubs. These species fell within the category of moderate water requirements, although some of them showed high water requirements. For each household, only one value of ks was proposed. This value was a linear combination of the fractional area occupied by turf and trees and shrubs.

The density factor modifies the species factor, adapting to the collective leaf area of all species in the landscape. If trees or shrubs only partially cover the soil surface, $k_{d}$ presents values ranging from 0.50 to 0.90 . If the soil surface is completely covered by plants, $k_{d}$ presents a value of 1.00. Finally, if two or more species coexist in the same piece of land (in different layers), $k_{d}$ values ranging from 1.10 to 1.30 are assigned. In this work, a value of $k_{d}$ of 1.20 was used in landscapes with turf and trees or shrubs. If the landscape only presented turf or trees and shrubs, a value of $k_{d}=1.00$ was used.

The microclimate factor depends on certain landscape characteristics which result in an increase or decrease of water requirements. In this work, a value of $k_{m c}=0.70$ was applied in all cases, since all households were surrounded by tall fences. This value corresponds to landscapes located in protected areas (Costello et al., 2000).

Net irrigation requirements $\left(I R_{n}\right)$ were determined from Eq. [3.2], in which Effective Precipitation (EP) was calculated using the method proposed by Brouwer and Heibloem (1986) for areas with slopes lower than 4-5\%:

$$
I R_{n}=K_{L} E T_{0}-E P
$$




\subsubsection{Irrigation Performance}

Irrigation performance was evaluated comparing irrigation water applied (IWA) with $I R_{n}$. IWA values were transformed from volume $\left(\mathrm{m}^{3}\right)$ to depth $(\mathrm{mm})$, considering the landscape area of each household. The ARIS index (Annual Relative Irrigation Supply), proposed by Malano and Burton (2001) was used as an indicator of irrigation performance. This index was obtained as a ratio between irrigation supply and irrigation requirements:

$$
\text { ARIS }=\frac{I W A}{I_{n}}
$$

The reported methodology is common to agricultural irrigation hydrology studies (Burt et al., 1997; Malano \& Burton, 2001; Lorite et al., 2004). As a consequence, parallels between local agricultural and landscape irrigation can be established and discussed.

Time correlation in household IWA and ARIS was analysed taking the three study years in pairs. The goal was to establish if the water use patterns (resulting in under- or overirrigation) were stable in time for the analysed households, or if new patterns appeared every year.

The SPSS software (Statistical Package for the Social Sciences, version 15 for Windows, SPSS Inc, Chicago, USA) was used for statistical analysis. Dendrograms of hierarchical conglomerates were used to classify households according to water use indexes. The goal of cluster analysis is to uncover groups of observations from initially unclassified data. Agglomerative hierarchical techniques are a class of clustering techniques in which, in each iteration, the number of clusters decrease and the number of individuals in each cluster increase. The task of the researcher is to decide which step in the analysis (or which number of clusters) will be used for research (Landau \& Everitt, 2004). 


\subsection{RESULTS AND DISCUSSION}

\subsubsection{Household landscape areas}

The initial database contained 134 households. In a first analysis of water records and aerial photographs, a total of 32 households were discarded due to the absence of landscape, zero landscape water use or presence of a swimming-pool. These last households were discarded because the type and volume of water used to supply the swimming-pools was unknown.

The size of the landscape areas ranged between 25 and $222 \mathrm{~m}^{2}$, with an average of $93 \mathrm{~m}^{2}$. This type of landscaping is smaller than the one used in previous studies located in the USA, in which areas as large as $500 \mathrm{~m}^{2}$ (Devitt et al., 2008) or 1,000 $\mathrm{m}^{2}$ (Aquacraft-Inc, 2003; Haley et al., 2007) were reported. In a residential area located in Barcelona (Spain), Domene and Saurí (2006) analysed landscapes with areas similar to this study: $83 \%$ of the landscapes were smaller than $100 \mathrm{~m}^{2}$.

The most common interval of landscape area in Montecanal was $60-80 \mathrm{~m}^{2}$, including $25 \%$ of the analysed households (Fig. 3.1a). $69 \%$ of the landscape areas fell in the interval of 60$120 \mathrm{~m}^{2}$. The percentage of landscape area to household area ranged between 9 and $60 \%$, with an average value of $34 \%$. The landscape area allocated to turf was on the average $60 \mathrm{~m}^{2}$ (Fig. 3.1b). This average value included extreme values such as households without turf and a household with $195 \mathrm{~m}^{2}$ of turf area. Turf area represented from 8 to $100 \%$ of the landscape area, being the most common range $65-75 \% .77 \%$ of the households had more than $50 \%$ of its landscape area covered with turf, while $31 \%$ of them used turf in more than $75 \%$ of the landscape area. Similar turf ratios were previously described in the USA (Aquacraft-Inc, 2003; Haley et al., 2007) and in Barcelona, Spain (Domene \& Saurí, 2006). In areas where water is scarce or expensive, turf ratios tend to be low (St.-Hilaire et al., 2008). In these cases, turf is replaced by species showing lower water requirements. A significant correlation $(P<0.01)$ was found in this study between landscape and turf areas, with Spearman's Rho coefficient $\left(r_{s}\right)$ of 0.724 . The relationship between landscape area and turf 
ratio was not significant. These results suggest that landowners in Montecanal are not restricted by water availability or cost in the planning of their landscape area.
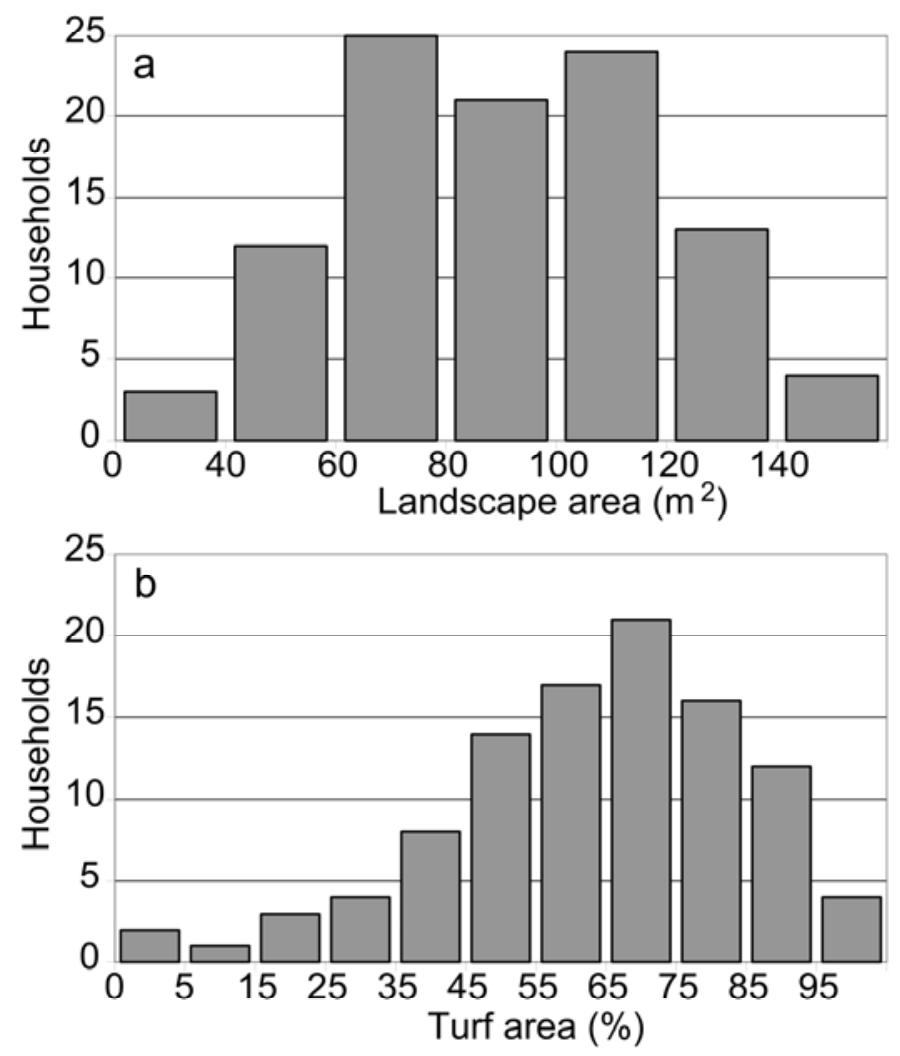

Figure 3. 1. Histograms of landscape area (a) and turf area (b) in Montecanal.

\subsubsection{Water use}

Figure 3.2 presents the total water volume used in the 102 studied households, separating indoor and landscape irrigation water. A clear seasonal effect could be observed on total water use. In the three years of study, total water use trends were very similar. The period with largest water use was Jul-Aug, with an average of $7,046 \mathrm{~m}^{3}$ (for a two-month period). The second was May-Jun (with an average of 6,275 $\mathrm{m}^{3}$ ), followed by Sep-Oct $\left(5,033 \mathrm{~m}^{3}\right.$ ) and Mar-Apr $\left(4,131 \mathrm{~m}^{3}\right)$. In winter periods only indoor water was used, with an average of 2,678 $\mathrm{m}^{3}$. Regarding total water use per household and day, a value of $0.80 \mathrm{~m}^{3}$ household per day was obtained, similar to that presented by Moreno et al. (2007) for households located in Madrid, Spain $\left(0.60 \mathrm{~m}^{3}\right.$ household ${ }^{-1}$ day $\left.^{-1}\right)$. 
Irrigation water represented $46 \%$ of the total annual water use in Montecanal. This value is consistent with values reported in the literature (in general, between 30 to $66 \%$ ) and is similar to the values reported by Hunt et al. (2001) in California and Loh and Coghlan (2003) in Western Australia, (46 and $56 \%$, respectively). During the irrigation season, the ratio of irrigation to total water was maximum in Jul-Aug (69 \%), and minimum in Mar-Apr (38\%).

Figure 3.2 also shows that the variability in irrigation water use is much higher than the variability in indoor water use, confirming the observations by White et al. (2004) and Moreno et al. (2007). The two main characteristics of household irrigation water (high volume and high seasonal variability) make the use of two separate distribution networks a very adequate solution. A positive correlation between total water use and irrigation water use was found $\left(r_{s}=0.775 ; P<0.01\right)$. This correlation was also found by Vickers (2001).

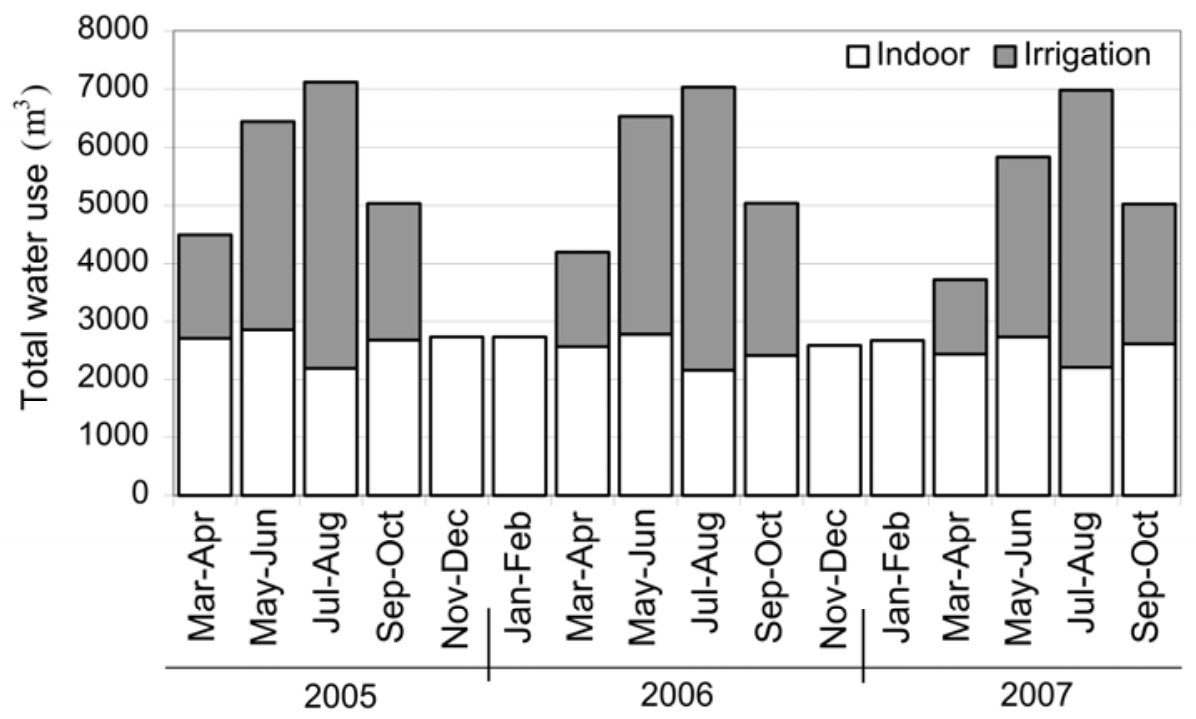

Figure 3. 2. Total water use, separating indoor and irrigation water.

The average use of indoor water amounted to $25.1 \mathrm{~m}^{3}$ per household in a two-month period, corresponding to $0.50 \mathrm{~m}^{3}$ household ${ }^{-1}$ day ${ }^{-1}$ (Fig. 3.3a). Loh and Coghlan (2003) reported a similar value of $0.42 \mathrm{~m}^{3}$ household ${ }^{-1}$ day $^{-1}$. The standard deviation of bi-monthly indoor water use was similar in all seasons and presented high values, with an average of 
$12.3 \mathrm{~m}^{3}$. Some seasonality could be observed in indoor water use, with maxima in May-Jun $\left(27.3 \mathrm{~m}^{3}\right)$ and minima in Jul-Aug $\left(21.4 \mathrm{~m}^{3}\right)$. This seasonality in indoor water use is related to the local holiday habits, and was reported by Moreno et al. (2007), while in Australia, Loh and Coghlan (2003) did not find any time variability.

The average bi-monthly indoor water use in winter months was $26.3 \mathrm{~m}^{3}, 4.8 \%$ higher than the average of $25.1 \mathrm{~m}^{3}$. Several authors (Syme et al., 2004; White et al., 2004; Endter-Wada et al., 2008) proposed to estimate indoor water use as the difference between total water use and indoor water consumption in winter, assuming that all winter water consumption is performed indoor. The dual water records used in Montecanal permitted testing of this hypothesis, to conclude that the method would have systematically underestimated outdoor water use in Jul-Aug, the period with highest irrigation requirements, by $23 \%$. As a consequence, a local study of yearly indoor water use seems to be required before adopting the hypothesis of constant indoor water use.

Figure 3.3b presents bi-monthly irrigation water use, expressed in depth units. The irrigation trends were similar in the three years of study, with maxima in Jul-Aug (average of $532 \mathrm{~mm}$ ), followed by May-Jun (380 mm), Sep-Oct (279 mm) and Mar-Apr (167 mm). Irrigation system automation is widespread in this type of household developments (Moreno et al., 2007). This explains the peak water use in a period when many houses are not occupied due to summer vacations. The values of water use for the same two-month period in the different years were relatively heterogeneous. Variability among households was quite high, as revealed by the high values of SD. 

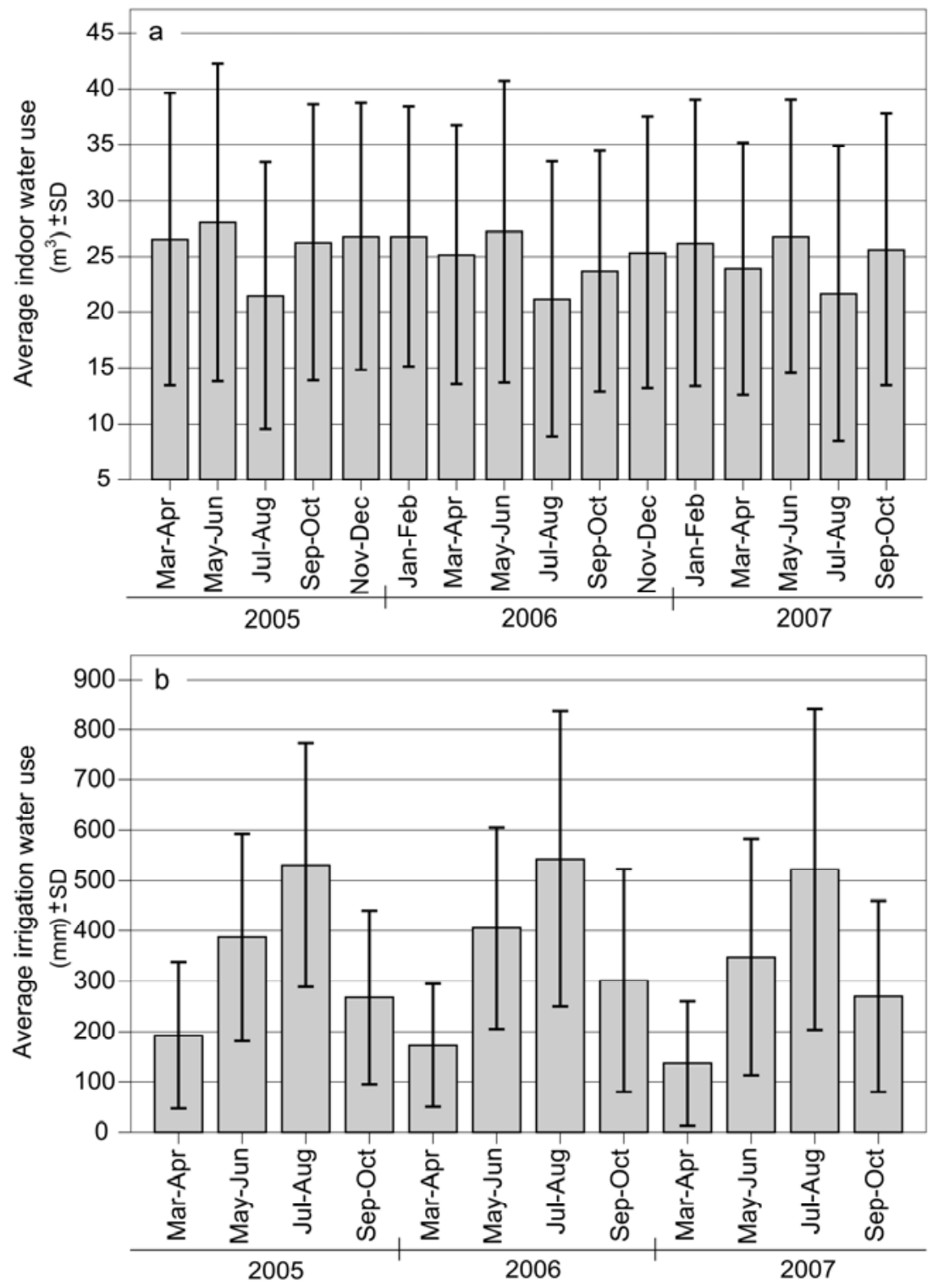

Figure 3. 3. Average indoor water use (a) and average irrigation water use (b) from the study periods from the years 2005, 2006 and 2007. Error bars indicate \pm standard deviation (SD) among households.

Moreno et al. (2007) reported that irrigation water use increased with temperature and decreased with precipitation. The comparison of Montecanal water use data and meteorological data (Table 3.1) suggests that users base irrigation scheduling on ambient temperature. The correlation between average temperature and average irrigation water use was significant $\left(r_{s}=0.958, P<0.01\right)$. However, the precipitation peaks presented in 2005 (May-Jun), 2006 (Sep-Oct) and 2007 (Mar-Apr) could not be statistically related to a 
decrease in irrigation water use. Therefore, in general, Montecanal water users did not stop their irrigation systems following intense precipitation events.

The relationship between landscape and turf areas on one hand and volume of irrigation water use on the other was assessed. Positive, significant correlations $(P<0.01)$ were obtained between irrigation water volume and landscape and turf areas (correlation coefficients of 0.450 and 0.307 , respectively). Similar relationships were found by Syme et al. (2004), Moreno et al. (2007) and Devitt et al. (2008). A significant correlation could not be found between landscape or turf areas and irrigation water depth $(\mathrm{mm})$. However, negative correlations have been reported between irrigation depth and irrigated area in agricultural irrigation (Clemmens \& Dedrick, 1992; Dechmi, Playán, Faci \& Tejero, 2003).

\subsubsection{Irrigation requirements}

The species factor $\left(k_{s}\right)$ ranged between 0.55 (all landscape area with trees or shrubs) and 0.82 (all landscape area with turf), with an average of 0.72 . In 91 of the 102 households, turf and trees or shrubs shared the landscape area, while in the remaining 11 households soil surface was only occupied by either turf or trees and shrubs.

The average $K_{L}$ was 0.60 , ranging from 0.39 to 0.69 . The most common range of values was 0.60-0.64, which included $28 \%$ of Montecanal households. A total of 75 households (74 \%) presented $\mathrm{K}_{\mathrm{L}}$ values between 0.56 and 0.69 . Montecanal $\mathrm{K}_{\mathrm{L}}$ resulted somewhat smaller than the values reported in the literature (Kjelgren et al., 2000; Morari \& Giardini, 2001; White et al., 2004; Haley et al., 2007 and Endter-Wada et al., 2008), with differences being due to local climatic factors and landscaping preferences. The calculated $\mathrm{K}_{\mathrm{L}}$ values were closely related to the percentage of turf in each household. In fact, both variables resulted significantly correlated $\left(r_{s}=0.937 ; P<0.01\right)$. 
Figure 3.4 presents the net irrigation requirements corresponding to each two-month period. The highest values appeared in summer periods, with Jul-Aug showing the most pronounced peaks (with an average value of $229 \mathrm{~mm}$ ). The average $\mathrm{IR}_{\mathrm{n}}$ in May-Jun was 166 $\mathrm{mm}$. Mar-Apr and Sep-Oct $I \mathrm{R}_{\mathrm{n}}$ showed a large variability among the study years. In Mar-Apr, $I R_{n}$ fluctuated from $19 \mathrm{~mm}$ in 2007 to $116 \mathrm{~mm}$ in 2005, while in Sep-Oct, $I R_{n}$ ranged from 42 $\mathrm{mm}$ in 2006 to $112 \mathrm{~mm}$ in 2007. Among the irrigated periods, minimum $\mathrm{IR}_{\mathrm{n}}$ was observed in Mar-Apr 2007 and Sep-Oct 2006, in coincidence with the above mentioned precipitation events (Table 3.1). Among households, $I_{n}$ presented much lower variability than IWA. The inter-household variability in $I R_{n}$ was only due to $K_{L}$.

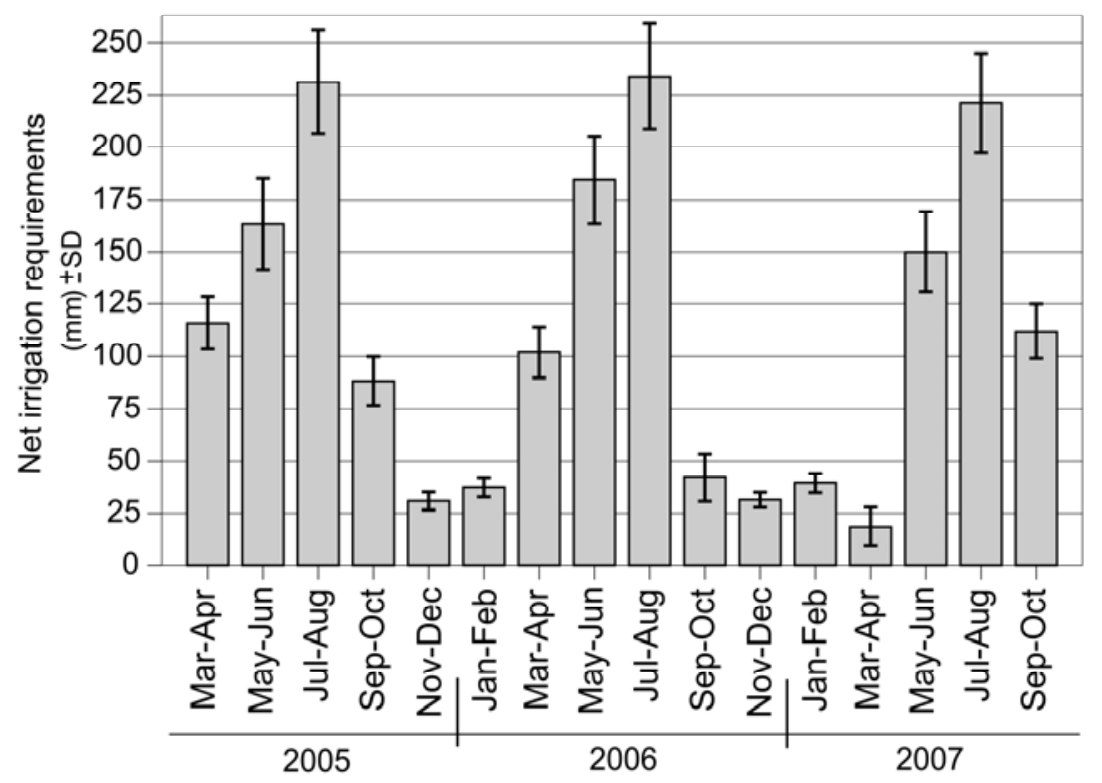

Figure 3. 4. Net irrigation requirements $\left(I R_{n}\right)$ for the study periods. Error bars indicate \pm standard deviation (SD) among households.

\subsubsection{Irrigation performance: Comparing $I R_{n}$ and IWA}

Comparison between $I R_{n}$ and IWA is presented in Table 3.2 for the different study periods. In annual averages, IWA was always higher than $I R_{n}\left(1,359\right.$ and $555 \mathrm{~mm}$ for IWA and $I R_{n}$, respectively). A clear relationship could not be established between both variables on a yearly basis, suggesting that landowners did not use irrigation water requirements 
information to schedule irrigation. Inter-household SD values were high for IWA, with an average of $677 \mathrm{~mm}$. The corresponding value for $I_{\mathrm{n}}$ was $67 \mathrm{~mm}$.

Regarding average bi-monthly data, Mar-Apr and Sep-Oct $I R_{n}$ were similar, while Sep-Oct IWA was much higher than Mar-Apr IWA. These results further support the trend to overirrigate during Sep-Oct, which was previously described by Kjelgren et al. (2000) and Hunt et al. (2001) for the fall season. Apparently landowners did not react on time to the decrease in water requirements by adjusting their irrigation controllers. For instance, Hunt et al. (2001), reported that $68 \%$ of residential users changed their irrigation schedule a maximum of four times during the year, a number that seems insufficient to ensure proper water use. The large inter-household IWA variability indicates that water application decisions were largely subjective. This issue has been analysed in research works aiming at identifying and modelling the motivations governing household irrigation scheduling decision-making (Domene \& Saurí, 2003; Syme et al., 2004; Parés-Franzi et al., 2006 and Endter-Wada et al., 2008).

Table 3.2. Basic statistics of net irrigation requirements $\left(\mathrm{IR}_{n}\right)$ and irrigation water applied (IWA) in the study periods.

\begin{tabular}{|c|c|c|c|c|c|}
\hline & & $\begin{array}{c}I_{\mathrm{n}} \\
(\mathrm{mm})\end{array}$ & $\begin{array}{l}S D I R_{n} \\
(\mathrm{~mm})\end{array}$ & $\begin{array}{l}\text { IWA } \\
\text { (mm) }\end{array}$ & $\begin{array}{c}\text { SD IWA } \\
\text { (mm) }\end{array}$ \\
\hline \multirow{3}{*}{$\stackrel{\frac{\alpha}{4}}{\underset{\nu}{\nu}}$} & 2005 & 599 & 70 & 1,378 & 629 \\
\hline & 2006 & 563 & 70 & 1,422 & 681 \\
\hline & 2007 & 502 & 65 & 1,276 & 722 \\
\hline \multirow{4}{*}{$\frac{O}{\frac{0}{x}}$} & Mar-Apr & 79 & 11 & 167 & 131 \\
\hline & May-Jun & 166 & 21 & 380 & 213 \\
\hline & Jul-Aug & 229 & 25 & 532 & 285 \\
\hline & Sep-Oct & 81 & 12 & 279 & 195 \\
\hline
\end{tabular}


A significant correlation could be established between $I R_{n}$ and IWA, $\left(r_{s}=0.481, P<0.01\right)$. When this analysis was performed separately for each household, a significant relationship $(P<0.01)$ could only be established for 55 households. In 77 households the relationship could be established with a significance of $\mathrm{P}<0.05$. Correlation largely improved when $T_{m}$ was used instead of $I R_{n}\left(r_{s}=0.958, P<0.01\right)$. When this correlation was analysed in each household, significance at the $\mathrm{P}<0.01$ level was observed in 69 households. These results confirm the relevance of average temperature in irrigation decision making.

Using the data presented by Salvador et al. (2010), the average seasonal net irrigation requirements of relevant crops in the Ebro basin can be compared to Montecanal IR (699 mm for alfalfa, $599 \mathrm{~mm}$ for corn and $488 \mathrm{~mm}$ for peach, vs. $555 \mathrm{~mm}$ in Montecanal). However, private household irrigation uses much more water per unit area than pressurized agricultural irrigation. As an example, our data indicate that 1,359 $\mathrm{mm}$ were used in Montecanal landscape irrigation, while Salvador et al. (2010) reported on-farm average water use of $882 \mathrm{~mm}$ for alfalfa, $720 \mathrm{~mm}$ for corn and $568 \mathrm{~mm}$ for peach.

\subsubsection{Irrigation performance classification}

In order to classify the analysed households regarding to their irrigation performance, an analysis of hierarchical conglomerates was performed, based on the absolute difference between IWA and $I R_{n}$ for each two-month period. Four different groups $(A, B, C$ and $D)$ were identified, choosing values of "Rescaled Distance Clusters Combine" higher than 7 units. Group A was further divided in two subgroups ( $A 1$ and $A 2$ ), with a distance between subgroups of 3 units. The number of households was 33, 32, 6, 16 and 10 for groups A1, A2, $B, C$ and $D$, respectively. A total of 5 households could not be included in any group because the distance separating them to each group was too large. Figure 3.5 presents two types of graphs for each group. Scatter plots (left) use different symbols for each bi-monthly period and two lines: a solid line for the regression equation and a dashed line for the 1:1 line. Bar/line charts (right) present average IWA (in bars $\pm S D$ ) and $I R_{n}$ (in lines) for the households included in each group. 
Group A1 presented the lowest differences between IWA and IR $R_{n}$, with an average of $79 \mathrm{~mm}$. Differences were maximum during Jul-Aug, with an average of $115 \mathrm{~mm}$. The average inter household SD was $105 \mathrm{~mm}$. The regression line corresponding to group A1 was the closest to the $1: 1$ line, with a slope of 1.48 and a coefficient of determination $\left(R^{2}\right)$ of 0.33 .

In group A2 linear regression resulted in the highest determination coefficient $\left(R^{2}=0.53\right)$, although differences between IWA and $I R_{n}$ amounted to an average value of $223 \mathrm{~mm}$. The slope of the regression line was 2.49 , indicating excessive irrigation throughout the year.

Group $B$ includes households in which $I R_{n}$ was in general higher than IWA. The average difference was $-77 \mathrm{~mm}$. In this group (representing $6 \%$ of the classified households), the highest variability among years could be observed. Although in 2005 differences between IWA and $I R_{n}$ were minimum, in 2006 and 2007 irrigation water application was much lower than $I_{n}$. Apparently, a reduced number of users decided to apply a very small water depth. Irrigation was not suspended during the study period, and maintained some proportionality with landscape water requirements.

Groups $C$ and $D$ showed generalized overirrigation, which was more evident in group $D$, where the average difference between IWA and $I R_{n}$ was of 470 (347 mm for group C). In both groups Jul-Aug was the period with highest differences (average values of $508 \mathrm{~mm}$ in group $C$ and $658 \mathrm{~mm}$ in group D). In group C, the slope of the regression line was of 3.26. Group D was the only one in which the regression intercept was significant, with a value of $330 \mathrm{~mm}$. The regression slope was 2.05 . 

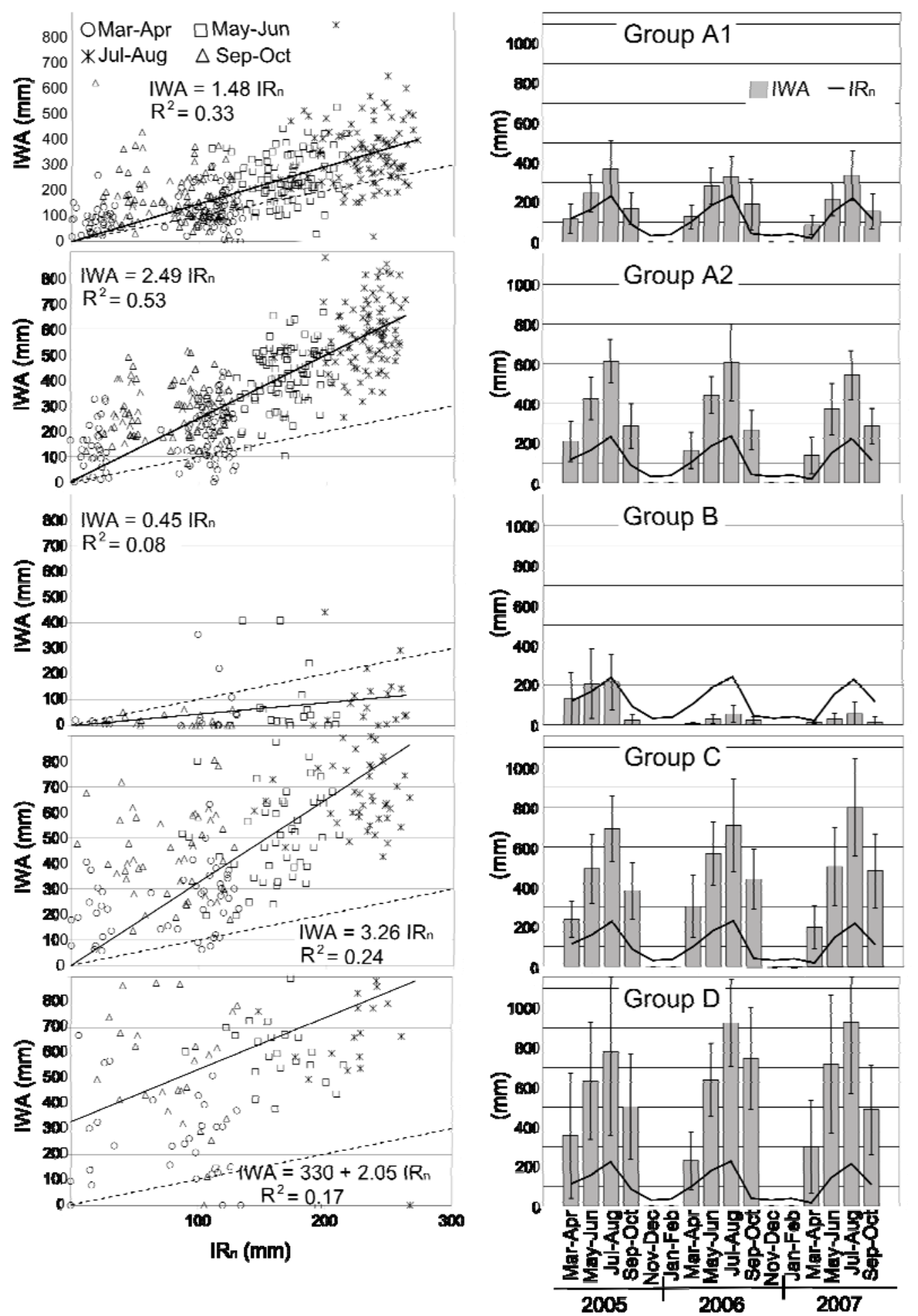

Figure 3. 5. Comparison between irrigation water applied (IWA) and net irrigation requirements $\left(\mathbb{R}_{n}\right)$ in each group of households: scatter plots (left) and bar diagrams (right) for each group of households. In the scatter plots, bi-monthly periods are represented by different symbols. Two lines are displayed: a solid line for the regression equation and a dashed line for the 1:1 line. In the bar diagrams, average IWA (in bars $\pm S D$ ) and $I R_{n}$ (in lines) are presented. Group $A 1$ shows small differences between IWA and $I R_{n}$; group $A 2$ shows moderate overirrigation; group $B$ includes underirrigated households; group $C$ shows large overirrigation, and group $\mathrm{D}$ severe overirrigation. 


\subsubsection{The ARIS irrigation performance index}

The average ARIS (all households and irrigation periods) was 2.52, with a SD of 1.39. These values confirm that overirrigation was a common practice in the study area. When the different irrigation years were considered, average ARIS values of 2.37, 2.60 and 2.59 were obtained for 2005, 2006 and 2007, respectively. These values are much larger than those commonly found in agricultural irrigation and higher than values reported in urban landscapes in Barcelona (Parés-Franzi et al. (2006) found that 56 \% of public garden were underirrigated) . In the Ebro basin, Salvador et al. (2010) reported ARIS values of 1.30, 1.21 and 1.18 for alfalfa, corn and peach, respectively, under pressurized irrigation. Agricultural ARIS values are typically lower in water stressed areas or in specific crops such as vineyards, olive tress and sunflower (Lorite et al., 2004). Similar results should be found when analysing water use in private landscapes of water-short cities or planted with drought-resistant species.

Figure 3.6 presents an ARIS histogram for the three years of study. The Figure confirms that about $10 \%$ of the landscapes were systematically underirrigated (a threshold ARIS value of 1.0 was used for this judgement). These households probably correspond to group " $B$ " in the irrigation performance classification. About $25 \%$ of the households exhibited ARIS values between 1.0 and 2.0, an interval that can be said to contain adequately irrigated households. This was the most frequent ARIS interval in 2007, with $27 \%$ of households. The most common range of ARIS values in 2005 and 2006 was 2.0-3.0, representing $45 \%$ of households in 2005 and $32 \%$ in 2006. This range of ARIS values was also a significant portion in 2007 , with $26 \%$ of households. 


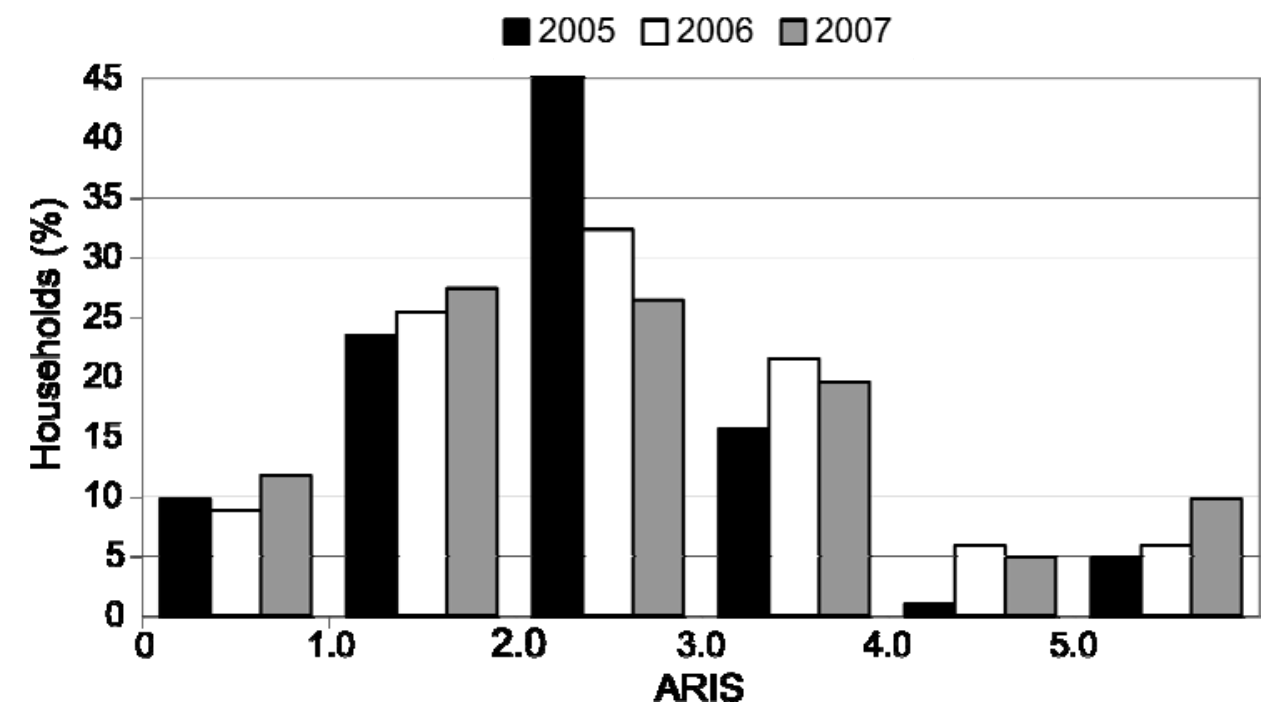

Figure 3. 6. ARIS histogram for the study years. ARIS was determined as the ratio of IWA to $I R_{n}$.

Significant correlations $(P<0.01)$ were found for ARIS and for IWA in all pairs of years. The average $r_{s}$ values were 0.734 for ARIS and 0.722 for IWA. Household irrigation practices regarding water application and irrigation performance primarily depended on the landowner, whose criteria showed remarkable time stability. The influence of water cost on irrigation decision making was not locally important, probably because the case study presented medium-high income and the cost of irrigation water was relatively low. As a consequence, users did not find an economic incentive to improve water use. This fact contributes to explain the overirrigation observed in the majority of households (Domene \& Saurí, 2003).

The correlation coefficient between ARIS and $K_{L}$ was significant $(P<0.05)$ with a $r_{S}$ of -0.238 , indicating an inverse relationship between ARIS and $\mathrm{K}_{\mathrm{L}}$. Landowners specializing in turf produce irrigation schedules more adjusted to water requirements (high $\mathrm{K}_{\mathrm{L}}$ is associated with large turf are percentage). Trees and shrubs were clearly overirrigated in the study area. Hunt et al. (2001) reported that $38 \%$ of landowners thought that trees and shrubs required as much irrigation water as turf. A significant, negative relationship was found between ARIS and landscape area $\left(r_{s}=-0.155, P<0.01\right)$, turf area $\left(r_{s}=-0.247, P<0.01\right)$ and percentage of turf area $\left(r_{s}=-0.225, P<0.01\right)$. Small landscapes resulted in the highest overirrigation, in agreement with results previously reported by Endter-Wada et al., (2008). 


\subsection{CONCLUSIONS}

In this work, urban irrigation water use in private landscapes (with an average area of $93 \mathrm{~m}^{2}$ ) has been analysed taking advantage of the infrequent dual water supply network installed at the residential area of Montecanal (Zaragoza, Spain). The average total (indoor plus irrigation) water use was $0.80 \mathrm{~m}^{3}$ household ${ }^{-1} \mathrm{day}^{-1}$. Irrigation water use amounted to $46 \%$ of the total water use (ranging from $38 \%$ in Mar-Apr to $69 \%$ in Jul-Aug).

Regarding indoor water use, maximum bi-monthly values were found in May-Jun, with an average of $27.3 \mathrm{~m}^{3}$. Minimum indoor water use was found in Jul-Aug $\left(21.4 \mathrm{~m}^{3}\right.$ on the average). The dual water network permitted estimation of the error resulting from the estimation of irrigation water volume as the difference between total water and winter indoor water use. This methodology resulted in an underestimation of bi-monthly irrigation water by up to $23 \%$. We believe that this summer reduction in indoor water use is related to the holiday habits in Spain, which concentrate vacations in the months of July and August, and very often imply leaving the residence. Specific water meters seem to be required for detailed analyses of irrigation water use in private households, at least in the local conditions.

Average air temperature largely determined irrigation water use $\left(r_{s}=0.958\right)$. The precipitation peaks registered during the study period did not influence the volume of irrigation water. Overirrigation was common in the three years of study, with average IWA higher than $I R_{n}\left(1,359\right.$ and $554 \mathrm{~mm}$, respectively). In Mar-Apr and Sep-Oct the values of $I R_{n}$ were very similar. However, in Sep-Oct, IWA values were much higher than in Mar-Apr, confirming previous findings pointing at generalized landscape overirrigation at the end of the irrigation season.

Hierarchical conglomerates were applied to the classification of irrigation water use in the different households. Four groups were identified, differing in the distance between IWA and $I R_{n}$. The A1 subgroup, containing $34 \%$ of the households, was the only one resulting in 
adequate irrigation. Of the remaining groups, three showed intense overirrigation, while one showed underirrigation in $6 \%$ of the households. The analysis of the ARIS index also pointed at generalized overirrigation, with an inter-annual average value of 2.52. Significant time correlations were identified for household IWA and ARIS, suggesting that landowners applied their inefficient irrigation criteria in a consistent way. The local combination of high income and low irrigation water cost seems to be related to the observed low irrigation performance. Under these circumstances, users may find the aesthetics of landscape and irrigation more important than conserving water.

The prospects for water conservation in local landscape irrigation are very important. Even if urban water use is not the main water sink in the Ebro basin, significant improvements can be expected from improved irrigation scheduling. Further analysis of household irrigation systems and practices could lead to additional water conservation through improved irrigation uniformity, night sprinkler irrigation and the design of different irrigation schedules for different landscape areas within the same household. Optimising private landscape irrigation seems to be more complex than optimizing agricultural irrigation, due to the differences in the perception of water cost and benefits. 


\subsection{REFERENCES}

Allen R.G., Pereira L.S., Raes D. \& Smith M. (1998). Crop evapotranspiration: guidelines for computing crop water requirements. FAO Irrigation and Drainage Paper 56. FAO, Rome, Italy.

Aquacraft-Inc (2003). Analysis of Operation of WeatherTRAK Controller in Field Conditions During 2002. Report on Performance of ET Based Irrigation Controller. Retrieved from http://www.aquacraft.com/Download_Reports/WeatherTRAK_2001_Study Report.pd $\underline{f}$

Ayuntamiento de Zaragoza (1999). Plan General de Ordenación Urbana de Zaragoza. Memoria Informativa. (General Urban Plan of Zaragoza. Information Report). Zaragoza, Spain. Retrieved from

http://www.zaragoza.es/ciudad/urbanismo/planeamiento/pgouz/memoria.htm [in Spanish].

Ayuntamiento de Zaragoza (2004). Ordenanza Fiscal no 24.25. Tasa por la prestación de servicios de abastecimiento de agua potable y saneamiento de aguas residuales (Tax Ordinance No. 24.25. Fee for the provision of potable water supply and wastewater treatment). Ordenanzas municipales. Zaragoza, Spain. Retrieved from http://www.zaragoza.es/contenidos/normas/ord fiscales/2004/ordenanza 24 25.pdf [in Spanish].

Bauman, D.D., Boland J.J. \& Hanemann W.M. (1998) Urban Water Demand Management and Planning. (pp. 77-94). McGraw- Hill, New York, USA.

Boland, J.J., Dziegielewski, B., Baumann, D.D. \& Opitz, E.M. (1984). Influence of price and rate structures on municipal and industrial water use. U.S. Army Corps of Engrs. Inst. For Water Resour., Fort Belvoir, Va.

Brouwer, C. \& Heibloem, M. (1986). Irrigation Water Management: Irrigation Water Needs. Training manual number 3. FAO, Rome, Italy. 
Brown, P. W., Mancino, C. F., Young, M. H., Thompson, T. L., Wierenga, P. J. \& Kopec, D. M. (2001). Penman Monteith Crop Coefficients for Use with Desert Turf Systems. Crop Sci., 41(4), 1197-1206.

Burt, C.M., Clemmens, A.J., Strelkoff, T.S., Solomon, K.H., Bliesner, R.D., Hardy, L.A., ... Eisenhauer, D.E. (1997). Irrigation performance measures: efficiency and uniformity. J. Irrig. Drain. E-ASCE., 123 (6), 423-442.

Clemmens, A. J. \& Dedrick, A. R. (1992). Identifying factors that influence farm water use. Technical Paper in: Conferencia Regional Panamericana, Mazatlán, Sinaloa, México.

Confederación Hidrográfica del Ebro (2010). Información Básica de la cuenca del Ebro. (Basic information of Ebro basin). Ministerio de Medio Ambiente y Medio Rural y Marino, Gobierno de España. Retrieved from http://www.chebro.es [in Spanish].

Contreras, F., González, A., López, J. \& Calvo, A. (2006). Estimación de necesidades hídricas para especies de jardín en la región de Murcia: Adaptación de WUCOLS y utilización del sistema de información agraria de Murcia. (Estimated water needs for species of garden in the region of Murcia: Adaptation of WUCOLS and use of agricultural information system of Murcia.). Technical paper in: III Jornadas Ibéricas de Horticultura Ornamental. Almería, Spain. [in Spanish].

Costello, L. \& Jones, K.S. (1994). WUCOLS. Water Use Classification of Landscape Species: A Guide to the Water Needs of Landscape Plants. University of California, Cooperative Extension. Sacramento, California, USA. Retrieved from http://ucce.ucdavis.edu/files/filelibrary/1726/15359.pdf

Costello, L.R., Matheny, N.P. \& Clark, J.R. (2000). A Guide to Estimating Irrigation Water Needs of Landscape Plantings in California. The Landscape Coefficient Method and WUCOLS III. University of California, Cooperative Extension. Sacramento, $\begin{array}{llll}\text { California, USA. } & \text { Retrieved }\end{array}$ http://www.water.ca.gov/wateruseefficiency/docs/wucols00.pdf

Davis, S. L., Dukes, M. D. \& Miller, G. L. (2009). Landscape irrigation by evapotranspiration-based irrigation controllers under dry conditions in Southwest Florida. Agr. Water Manage., 96(12), 1828-1836. doi: 10.1016/j.agwat.2009.08.005. 
Dechmi, F., Playán, E., Faci, J. M. \& Tejero, M. (2003). Analysis of an irrigation district in northeastern Spain: I: Characterisation and water use assessment. Agr. Water Manage., 61(2), 75-92. doi: 10.1016/S0378-3774(03)00020-9.

Devitt, D.A., Carstensen, K. \& Morris, R.L. (2008). Residential Water Savings Associated with Satellite-Based ET Irrigation Controllers. J. Irrig. Drain. E-ASCE, 134(1), 74-82. doi: 10.1061/(ASCE)0733-9437(2008)134:1(74).

Domene, E. \& Saurí, D. (2003). Modelos urbanos y consumo de agua. El riego de jardines privados en la región metropolitana de Barcelona. (Urban models and water consumption. Irrigation of private gardens in the metropolitan area of Barcelona). Investigaciones Geográficas, 32(2003), 5-17. [in Spanish].

Domene \& Saurí (2006). Urbanisation and Water Consumption: Influencing Factors in the Metropolitan Region of Barcelona. Urban Stud., 43 (9), 1605-1623. doi: $10.1080 / 00420980600749969$

Endter-Wada, J., Kurtzman, J., Keenan, S., Kjelgren, R. \& Neale, C. M. U. (2008). Situational waste in landscape watering: residential and business water use in an urban Utah community. J. Am. Water Resour. As., 44(4), 902-920. doi: 10.1111/j.17521688.2008.00190.x

Gobierno de Aragón (2008). Servicio de Información Territorial de Aragón (SITAR).(Land Information Service of Aragón, SITAR) Retrieved from http://sitar.aragon.es [in Spanish].

Haley, M.B., Dukes, M.D. \& Miller, G.L. (2007). Residential Irrigation Water Use in Central Florida. J. Irrig. Drain. E-ASCE, 133(5), 427-434. doi: 10.1061/(ASCE)07339437(2007)133:5(427).

Hirsch, F. (1976). Social limits to growth. Harvard University Press, Cambridge, Massachusetts, USA.

Hunt, T., Lessick, D., Berg, J., Wiedmann, J., Ash, T., Pagano, D. ... Bamezai, A. (2001). Residential Weather-Based Irrigation Scheduling: Evidence from the Irvine "ET Controller" Study. Retrieved from http://www.irrigation.org/swat/images/irvine.pdf 
Hurd, B.H., St. Hilaire, R. \& White, J.M. (2006). Residential landscapes, homeowner attitudes, and water-wise choices in New Mexico. Hortscience, 16(2), 241-246.

Kjelgren, R., Rupp, L. \& Kilgren, D. (2000). Water Conservation in Urban Landscapes. Hortscience, 35(6), 1037-1040.

Landau, S. \& Everitt, B.S. (2004). A Handbook of Statistical Analyses using SPSS. Chapman \& Hall/CRC Press LLC. ISBN 1-58488-369-3.

Loh, M.T. \& Coghlan, P. (2003). Domestic Water Use Study in Perth, Western Australia. 1998-2001, Water Corporation. Australian Greenhouse Office, Perth, Western $\begin{array}{llll}\text { Australia, } & \text { Australia. } & \text { Retrieved }\end{array}$ http://www.watercorporation.com.au/ files/publicationsregister/12/Domestic water use study.pdf

Lorite I.J., Mateos L. \& Fereres E. (2004). Evaluating irrigation performance in a Mediterranean environment - II. Variability among crops and farmers. Irrigation Sci., 23 (2), 85-92. doi: 10.1007/s00271-004-0096-8.

Malano, H. \& Burton, M. (2001). Guidelines for benchmarking performance in the irrigation and drainage sector. FAO, Knowledge Synthesis Report, Rome, Italy.

McCready, M. S., Dukes, M. D. \& Miller, G. L. (2009). Water conservation potential of smart irrigation controllers on St. Augustinegrass. Agr. Water Manage., 96(11), 16231632. doi: 10.1016/j.agwat.2009.06.007.

Ministerio de Medio Ambiente y Medio Rural y Marino, Gobierno de España (2008). Estaciones Agroclimáticas. Red SIAR. (Agrometeorological stations. SIAR network) Retrieved from http://www.mapa.es/siar/Informacion.asp [in Spanish].

Morari, F. \& Giardini, L. (2001). Estimating evapotranspiration in the Padova Botanical Garden. Irrigation Sci., 20(3), 127-137. doi: 10.1007/s002710100036.

Moreno, T., Ibáñez, J.C. \& Cubillo, F. (2007). Los usos finales del agua como base para la caracterización y predicción de la demanda en la Comunidad de Madrid. (The end uses of water as a base for the characterization and prediction of demand in the Community of Madrid) Technical paper in: V Congreso Nacional de la Ingeniería Civil. Desarrollo y Sostenibilidad en el marco de la ingeniería. Sevilla, Spain. Retrieved from 
Spanish].

Parés-Franzi, M., Saurí-Pujol, D. \& Domene, E. (2006). Evaluating the Environmental Performance of Urban Parks in Mediterranean Cities: An Example from the Barcelona Metropolitan Region. Environ. Manage., 38 (5), 750-759. doi: 10.1007/s00267-0050197-z

Quails, R. J., Scott, J. M. \& DeOreo, W. B. (2001). Soil moisture sensors for urban landscape irrigation: Effectiveness and reliability. J. Am. Water Resour. As., 37(3), 547559.

Renzetti, S. (2002). The Economics of Water Demands. Kluwer Academic Press, Norwell, Massachusetts.

Salvador, R., Martínez-Cob, A., Cavero, J. \& Playán, E. (2010). Seasonal on-farm irrigation performance in the Ebro basin (Spain): crops and irrigation systems. Agric. Wat. Manage. DOI: 10.1016/j.agwat.2010.10.003.

St.-Hilaire, R., Arnold, M., Wilkerson, D.C., Devitt, D.A., Hurd, B.H., Lesikar, B.J., ... Zoldoske, D.F. (2008). Efficient Water Use in Residential Urban Landscapes. Hortscience, 43(7), 2081-2092.

Syme, G.J., Shao, Q., Po, M. \& Campbell, E. (2004). Predicting and understanding home garden water use. Landscape Urban Plan., 68(1), 121-128. doi: 10.1016/j.landurbplan.2003.08.002.

Vickers, A. (2001). Handbook of Water Use and Conservation: Homes, Landscapes, Business, Industries, Farms. Waterplow Press, Amherst, Massachusetts. ISBN 10: 1931579-07-5

White, R., Havalak, R., Nations, J., Pannkuk, T., Thomas, J., Chalmers, D. \& Dewey, D. (2004). How Much Water is Enough? Using PET to Develop Water Budgets for Residential landscapes. Texas Water Resources Institute. College Station, Texas, USA. Retrieved from http://repository.tamu.edu/bitstream/handle/1969.1/6100/tr271.pdf?sequence=1 